\title{
Penyuluhan dan Pemberian Minuman Madu Jahe Pada Ibu Hamil Trimester Satu Dengan Emesis Gravidarum
}

\author{
Retno Widowati ${ }^{1,2 *}$, Siti Muslihah ${ }^{2}$, Shinta Novelia², Dewi Kurniati² \\ ${ }^{1}$ Program Studi Magister Biologi, Sekolah Pascasarjana, Universitas Nasional, Indonesia \\ ${ }^{2}$ Program Studi Kebidanan, Fakultas Ilmu Kesehatan, Universitas Nasional, Indonesia \\ * retno.widowati@civitas.unas.ac.id
}

\begin{abstract}
ABSTRAK
Ibu hamil trimester satu seringkali memiliki permasalahan emesis gravidarum (EG) atau mual muntah yang bila tidak ditangani dengan baik bisa mengganggu kesehatan ibu dan janin. Pengabdian kepada masyarakat $(\mathrm{PkM})$ bertujuan memberi penyuluhan mengenai EG pada ibu hamil trimester satu, serta manfaat minuman madu jahe untuk mengatasi EG. Selain itu dilakukan monitoring penurunan EG pada ibu yang minum madu jahe selama tujuh hari. Penyuluhan dilakukan pada hari Senin tanggal 16 Desember 2019, di Balai Desa Legok, Jl. Jaya Ningrat No.99, Kecamatan Legok, Tangerang, Banten. Sarana PkM berupa leaflet, madu, daftar hadir, lembar observasi, dan spanduk. Jumlah peserta penyuluhan sebanyak 20 orang. Penyuluhan didampingi oleh bidan koordinator, bidan program dan kader posyandu di Wilayah Kerja Puskesmas Legok. Penyuluhan dilakukan dengan pembukaan dan doa; pembagian leaflet dan paket goody bag yang berisi madu, susu, snak sehat dan minuman; penyuluhan dengan materi sesuai tujuan; tanya jawab; dan penutup. Pelaksanaan monitoring penurunan EG dilakukan pada ibu hamil yang bersedia ikut serta dan dilaksanakan selama tujuh hari. Ibu menyiapkan sendiri minuman madu jahe sesuai resep yang diberikan dan diminum setiap hari pada pagi dan sore hari, dengan pendampingan tim pelaksana. Pengukuran EG sebelum dan sesudah minum madu jahe dengan kuesioner instrument PUQE. Hasil menunjukkan penyuluhan bagi ibu hamil sangat bermanfaat dan terdapat perbedaan signifikan $[\mathrm{p}(0,004)<\alpha(0,05)]$ emesis gravidarum pada ibu hamil trimester satu, sebelum dan sesudah minum madu jahe secara teratur, selama tujuh hari.
\end{abstract}

Kata Kunci: Minuman Jahe Madu, Emesis Gravidarum, Ibu Hamil

Received: May, 28, 2020

Revised: June 16, 2020

Accepted: July 24, 2020

This is an open-acces article distributed under the terms of the Creative Commons Attribution-ShareAlike 4.0 International License.

\section{PENDAHULUAN}

Emesis gravidarum adalah gejala mual dan biasanya disertai muntah yamg disertai pada ibu hamil trimester satu. Emesis gravidarum adalah pengalaman umum dalam kehamilan, mempengaruhi $70-80 \%$ dari semua wanita hamil. Meskipun sebagian besar wanita dengan emesis gravidarum memiliki gejala terbatas pada trimester pertama, 


\section{Journal of Community Engagement in Health}

http://jceh.org

ISSN: 2620-3758 (print); 2620-3766 (online)

https://doi.org/10.30994/jceh.v3i2.56

Vol.3 No.2. Sep 2020. Page.163-170

sebagian kecil wanita mengalami perjalanan yang berkepanjangan dengan gejala memanjang hingga melahirkan. Wanita dengan mual dan muntah parah selama kehamilan dapat mengalami hiperemesis gravidarum, suatu entitas yang berbeda dari emesis gravidarum, yang jika tidak diobati dapat mempengaruhi kesejahteraan ibu dan janin (Wylde et al., 2016) hingga menyebabkan morbiditas ibu dan janin yang signifikan (Lee \& Saha, 2011; Herrel, 2014). Emesis gravidarum pada kehamilan dapat menimbulkan gangguan nutrisi, dehidrasi, kelemahan, penurunan berat badan, serta ketidakseimbangan elektrolit (Runiari, 2010).

Emesis gravidarum atau mual yang disertai muntah pada ibu hamil sering disebut juga morning sickness (Lee \& Saha, 2011; Aly et al., 2013; Wylde et al, 2016). Walaupun dalam istilah asing diberi nama morning sickness bukan berarti hanya bisa terjadi pada pagi hari. Pada kenyataannya, banyak juga wanita hamil yang mengalami hal ini di siang atau sore hari, bahkan di sepanjang hari (Lee \& Saha, 2011; Renityas, 2019 dalam Putri dan Hastina, 2020). Pertimbangan harus diberikan kepada kesehatan mental ibu sebagai efek emesis gravidarum adalah manifestasi melampaui fisik dan pengaruh kemampuan ibu untuk berpartisipasi dalam rutinitas harian dan interaksi sosial (Wylde et al., 2016).

Database medis menunjukkan bahwa estrogen, human chorionic gonadotropin (hCG), tiroksin dan insulin berkaitan dengan emesis gravidarum (Wylde et al, 2016). Meskipun patogenesis yang tepat dari emesis gravidarum belum diketahui (Herrel 2014, Wylde et al. 2016), secara luas diterima bahwa muntah gestasional dihasilkan dari berbagai faktor metabolisme dan endokrin, banyak berasal dari plasenta. Faktor yang paling terlibat adalah human chorionic gonadatropin (hCG). Hubungan antara hCG dan emesis gravidarum ini sebagian besar didasarkan pada hubungan temporal antara puncak emesis gravidarum dan puncak produksi hCG, yang keduanya terjadi antara usia kehamilan 12 dan 14 minggu. Hormon ovarium, estrogen dan progesteron, juga terlibat dalam patogenesis emesis gravidarum. Hal ni diketahui bahwa beberapa wanita mengalami mual saat menggunakan kontrasepsi oral. Progesteron dalam kombinasi dengan estrogen juga dapat berperan dalam emesis gravidarum. Progesteron mengurangi kontraktilitas otot polos dan dapat mengubah pengosongan lambung dan menyebabkan peningkatan mual dan muntah (Lee \& Saha, 2011).

Penatalaksanaan mual dan muntah pada kehamilan tergantung pada beratnya gejala. Pengobatan dapat dilakukan dengan cara farmakologi maupun non farmakologi. Terapi farmakologi dilakukan dengan pemberian antiemetik, antihistamin, antikolinergik, dan kortikosteroid (Runiari, 2010). Berbagai pilihan antiemetik (anti muntah) dan alami obat tersedia untuk mengurangi mual dan muntah (Wylde et al., 2016). Beberapa terapi farmakologis yang aman dan efektif tersedia untuk wanita yang tidak membaik dengan pengobatan awal (Herrel, 2014).

Namun demikian akan lebih baik jika ibu hamil mampu mengatasi masalah mual pada awal kehamilan dengan menggunakan terapi pelengkap nonfarmakologis terlebih dahulu. Hal ini dikarenakan terapi pelengkap nonfarmakologis bersifat noninstruktif, noninfasif, murah, sederhana, efektif dan tanpa efek samping yang merugikan (Runiari, 2010). Para ibu sering mencari bantuan dari para profesional untuk mengurangi gejala mual muntah mereka, tetapi perawatan tidak selalu berhasil. Pelengkap tertentu terapi (pengobatan herbal) biasanya dilakukan diantaranya adalah jahe, chamomile, peppermint, echinacea, cranberry dan raspberry adalah beberapa di antara ramuan yang digunakan tujuan ini (Aly et al., 2013). Selain itu terapi nonfarmakologi dilakukan di antaranya dengan cara pengaturan diet, dukungan emosional, akupuntur, aromaterapi, minuman madu jahe (Regina et al., 2011). 


\section{Journal of Community Engagement in Health}

http://jceh.org

ISSN: 2620-3758 (print); 2620-3766 (online)

https://doi.org/10.30994/jceh.v3i2.56

Vol.3 No.2. Sep 2020. Page.163-170

Madu adalah cairan manis yang berasal dari nektar tanaman yang diproses oleh lebah menjadi madu dan tersimpan dalam sel-sel sarang lebah. Madu memiliki manfaat dalam berbagai aspek, antara lain dari segi pangan, kesehatan, dan kecantikan. Madu sering digunakan sebagai bahan pemanis, penyedap makanan, dan campuran saat mengkonsumsi minuman. Selain itu, madu sering pula digunakan untuk obat obatan. Madu merupakan salah satu sumber makanan yang baik. Asam amino, karbohidrat, protein, beberapa jenis vitamin serta mineral adalah zat gizi dalam madu yang mudah diserap oleh sel-sel tubuh (Hutagalung, 2016).

Variasi madu berasal dari tumbuhan yang berbeda, menjadikan berbeda dalam penampilan, persepsi sensorik dan komposisi. Komponen utama nutrisi dan kesehatan yang relevan pada madu adalah karbohidrat, terutama fruktosa dan glukosa ada juga sekitar 25 oligosakarida yang berbeda. Meskipun madu adalah makanan berkarbohidrat tinggi, indeks glikemiknya bervariasi dalam kisaran yang luas dari 32 hingga 85 , tergantung pada sumber tumbuhannya. Madu mengandung sejumlah kecil protein, enzim, asam amino, mineral, elemen, vitamin, senyawa aroma dan polifenol. Komposisi, kontribusi nutrisi dari komponen-komponennya, efek fisiologis dan nutrisinya, menunjukkan bahwa madu memiliki beragam efek gizi dan kesehatan yang positif, jika dikonsumsi pada dosis yang lebih tinggi, 50 hingga 80 gram per asupan (Bodganov et al., 2008).

Jahe merupakan tanaman yang rimpangnya diketahui banyak khasiat dan yang telah dikenal sejak lama. Rimpang jahe dimanfaatkan, antara lain sebagai bumbu masak, minuman, serta permen dan juga digunakan dalam minuman obat atau jamu tradisional. Menurut Aly et al. (2013) jahe menghasilkan gingerol yang berpotensi aktif, yang dapat dikonversi menjadi shogaol, zingerone, dan paradol. Senyawa 6-gingerol mungkin bertanggung jawab atas rasa khas jahe. Zingerone dan shogaol ditemukan dalam jumlah kecil dalam jahe segar dan dalam jumlah besar kering atau produk yang diekstraksi. Jahe bekerja di dalam saluran pencernaan dengan meningkatkan tonus dan peristaltik akibat aksi antikolinergik dan anti-serotonin. Walaupun mekanisma tepat belum dipahami dengan jelas. Senyawa 6-gingerol dan 6-shogaol telah terbukti memiliki sejumlah aktivitas farmakologis, termasuk efek antipiretik, analgesik, antitusif, dan hipotensi. Runiari (2010) menjelaskan bahwa keungulan pertama jahe adalah kandungan minyak atsiri yang mempunyai efek menyegarkan dan memblokir reflek muntah, sedang gingerol dapat melancarkan peredaran darah dan saraf-saraf bekerja dengan baik. Hasilnya ketegangan bisa dicairkan, kepala jadi segar, mual muntah pun ditekan.

Beberapa hasil penelitian menunjukkan bahwa jahe merupakan bahan terapi untuk meredakan dan mengurangi rasa mual dan muntah. Selain itu jahe juga efektif dalam mengurangi mual muntah pada ibu hamil trimester pertama kehamilan dan menurunkan mual muntah pada ibu yang multigravida (Saswita \& Marisah, 2011). Dosis dan bentuk sediaan jahe yang digunakan untuk mengatasi mual dan muntah pada kehamilan perlu dipelajari lebih lanjut, jahe tampaknya mempunyai kelebihan, terutama pada sistem tubuh yang dipengaruhi efek muntah pada saluran gastrointestinal dan system saraf pusat. Kondisi ini menjelaskan mengapa jahe dapat mengurangi rasa mual dan muntah pada kehamilan.

Madu dan Jahe memiliki manfaat untuk mengurangi mual muntah pada kehamilan karena jahe memiliki kandungan minyak atsiri yaitu gingerol dan madu juga mengandung piridoksin, kedua zat tersebut sebagai anti chemoreseptor yang dapat memblok atau menghentikan zat serotonin, dopamine, astiklon, histamin dan neurokinin yang dapat mengaktifkan pusat muntah (Dipiro et al., 2015). Jahe tidak memiliki efek samping pada kehamilan dan madu yang kaya nutrisi dan enzim untuk untuk kebutuhan nutrisi ibu hamil 


\section{Journal of Community Engagement in Health}

http://jceh.org

ISSN: 2620-3758 (print); 2620-3766 (online)

https://doi.org/10.30994/jceh.v3i2.56

Vol.3 No.2. Sep 2020. Page.163-170

dan asupan gizi janin ketika jahe dan madu diminum secara bersamaan efek jahe lebih cepat karena madu mengandung enzim diatase, invertase, glukosa oksidase dan peroksidase untuk metabolisme sehingga lebih cepat diserap oleh tubuh (Herlinadiyaningsih et al., 2015). Menurut penelitian Herlinadiyaningsih et al. (2015) memberikan minuman kombinasi jahe dan madu digunakan sebagai salah satu pilihan terbaik dalam pengobatan mual dan muntah pada wanita hamil.

Untuk membuat minuman madu jahe, berikut adalah resep pembuatan minuman madu jahe adalah dengan cara mendidihkan air sebanyak dua setengah gelas. Dua ruas jahe yang sudah dikupas dimasukkan ke dalam air, direbus, hingga air berkurang menjadi lebih kurang setengah gelas, api dimatikan. Air jahe kemudian dimasukkan ke dalam gelas dan dicampur masing-masing gelas dengan satu sendok makan madu, setelah agak air jahe menjadi hangat. Minuman madu jahe diminum pagi dan sore hari.

\section{METODE}

Langkah-langkah kegiatan PkM penyuluhan dan pemberian minuman madu jahe pada ibu hamil trimester satu dengan emesis gravidarum adalah sebagai berikut:

\section{Tahap Persiapan}

a. Koordinasi dengan bidan setempat

Tahap ini merupakan tahap paling awal yang dilakukan, tim pelaksana berkoordinasi dengan bidan terkait program yang bertugas di Puskesmas Legok Kabupaten Tangerang. Koordinasi dilakukan untuk mengetahui permasalah ibu hamil yang dapat diatasi dengan melakukan hal mudah oleh ibu hamil itu sendiri.

b. Pemantapan dan penentuan lokasi, waktu dan sasaran penyuluhan

Tahap ini dilakukan dengan menentukan waktu penyuluhan, lokasi tempat penyuluhan dilakukan, dan ibu hamil sasaran penyuluhan dan pemberian minuman madu jahe. Pada tahap ini juga dilakukan pembuatan proposal pengabdian kepada masyarakat yang berisi latar belakang, tujuan, waktu, lokasi, sasaran serta metode dan pembiayaan pengabdian kepada masyarat. Proposal diajukan kepada Wakil

Rektor Bidang Penelitian, Pengabdian Masyarakat dan Kerjasama (PPMK) Universitas Nasional.

Proposal mendapat persetujuan dari pimpinan Universitas Nasional, dengan keluarnya SK Rektor tentang Proposal Pengabdian Kepada Masyarakat yang disetujui. Langkah selanjutnya adalah pembuatan surat resmi dari institusi Fakultas Ilmu Kesehatan Universitas Nasional kepada Kepala Puskesmas Legok, Kabupaten Tangerang untuk maksud tujuan dilakukannya pengabdian kepada masyarakat di Wilayah Kerja Puskesmas Legok, Kabupaten Tangerang.

c. Persiapan peralatan dan alat peraga.

Untuk memperlancar pelaksanaan PkM dilakukan pembuatan leaflet bagi peserta yang berisi tujuan, manfaat, resep pembuatan minuman madu jahe. Dengan adanya leaflet ini akan mempermudah ibu sasaran PkM untuk menyimak dan catatan dapat dibawa pulang ke rumah.

Selain itu pula disiapkan madu pada botol botol ukuran kecil yang akan dibagikan kepada ibu hamil, bila ibu hamil akan membuat minuman madu jahe di rumah. Agar pelaksanaan PkM lancar dan meriah, maka dibuatkan spanduk untuk ditempel pada dinding tempat pelaksanaan PkM.

Pada hari pelaksanaan PkM, juga disiapkan panganan kecil untuk ibu hamil dan susu ibu hamil sebagai bentuk dukungan tim pelaksana PkM kepada ibu hamil. 


\section{Tahap Pelaksanaan PkM.}

Tahap pelaksanaan PkM dibagi menjadi beberapa tahap yaitu tahap pelaksanaan penyuluhan, tahap pelaksanaan pengujian pemberian minuman madu jahe, tahap analisis hasil pengaruh pemberian minuman madu jahe

\section{A. Penyuluhan Minuman Madu Jahe.}

Penyuluhan dilakukan pada hari Senin, tanggal 16 November 2020, mulai pukul 09.00 - 12.00 WIB. Kegiatan dilakukan di Balai Desa Legok, Kecamatan Legok, Kabupaten Tengerang, Provinsi Banten.

Sasaran dari PkM berjumlah 20 ibu hamil trimester satu, yang tinggal di Wilayah Kerja Puskesmas Legok Kabupaten Tangerang. Kegiatan PkM ini didampingi pula oleh Bidan Koordinator, beberapa bidan, dan beberapa kader posyandu.

Tahap Pertama Penyuluhan:

i) Pembukaan dan Doa,

ii) Pembagian leaflet dan paket goody bag yang berisi madu, susu, snak sehat dan minuman.

iii) Kegiatan Penyuluhan dengan materi

a. Mengapa ibu hamil trimester pertama merasa mual dan kadang-kadang disertai muntah.

b. Kerugian kalau ibu hamil trimester tiga sering mual muntah

c. Manfaat minuman madu dan jahe untuk ibu hamil trimester satu dengan pengurangan emesis gravidarum

d. Resep membuat minuman madu jahe

iv) Tanya jawab

v) Penutup

\section{B. Observasi emesis gravidarum}

Untuk melihat pengaruh minum madu jahe pada ibu hamil trimester satu terhadap mual muntah, dilaksanakan observasi. Tahapan yang dilaksanakan adalah:

i) Meminta kesediaan ibu menjadi responden secara sukarela dimonitor mual muntahnya dan mengisi kuesioner instrument PUQE untuk mengkaji intensitas mual muntah selama 24 jam sebelum minum madu jahe.

ii) Ibu diberi minuman madu jahe sebanyak satu gelas, kemudian dilakukan observasi 20 menit setelah minum madu jahe untuk memastikan bahwa tidak terjadi respon negatif terhadap responden.

iii) Ibu diberi lembar observasi mual muntah untuk diisi di rumah. Ibu diminta membuat minuman madu jahe sesuai resep di rumah, dan diminum setiap pagi sore selama satu minggu.

iv) Tim pelaksana mendampingi ibu yang minum madu jahe untuk memonitor mual muntah selama tujuh hari.

v) Pada hari ke delapan tim pelaksana mengumpulkan lembar observasi yang telah diisi oleh ibu. Ibu juga diminta mengisi pengukuran skala mual.

vi) Hasil pengukuran emesis gravidarum dianalisis untuk membedakan mual muntah sebelum dan sesudah minum madu jahe selama tujuh hari.

\section{HASIL DAN PEMBAHASAN}

Kegiatan pengabdian kepada masyarakat tentang pemberian minuman madu jahe pada ibu hamil trimester satu dengan emesis gravidarum di wilayah kerja Puskesmas Legok, Kecamatan Legok, Kabupaten Tangerang, Provinsi Banten, tepatnya di Aula Desa 


\section{Journal of Community Engagement in Health}

http://jceh.org

ISSN: 2620-3758 (print); 2620-3766 (online)

https://doi.org/10.30994/jceh.v3i2.56

Vol.3 No.2. Sep 2020. Page.163-170

Legok. J1. Jaya Ningrat No.99, Legok dilaksanakan pada Hari Senin, Tanggal 16 November 2019. Kegiatan penyuluhan ini berjalan dengan lancar dan baik yang diikuti oleh ibu hamil trimester satu sebanyak 20 orang. Kesan dari peserta, kegiatan ini sangat bermanfaat bagi ibu hamil. Mereka dapat memanfaatkan minuman jahe madu untuk mengurangi emesis gravidarum. Selain mendapatkan madu, ibu hamil juga mendapatkan susu ibu hamil untuk meningkatkan gizi baik bagi ibu maupun bayi yang dikandungnya.

Hasil monitoring emesis gravidarum

Selama tujuh hari ibu trimester satu, sebanyak 16 orang, minum madu jahe dan dimonitoring emesis gravidarumnya. Pada keadaan sebelum minum madu jahe, ibu yang mengalami emesis gravidarum intensitas sedang sebanyak $8(50 \%)$ dan intensitas berat sebanyak $8(50 \%)$. Tidak ada ibu dengan intensitas emesis gravidarum ringan. Setelah minum madu jahe secara teratur selama tujuh hari, diperoleh hasil monitoring ibu yang emesis gravidarum intensitas berat menjadi $3(18,8 \%)$; emesis gravidarum intensitas sedang sebanyak 6 (37,5\%) dan emesis gravidarum ringan sebanyak 7 (43,8\%). Terdapat penurunan adanya perbedaan emesis gravidarum pada ibu, dari sebelum diberi madu jahe dan sesudah minum madu jahe (Tabel 1).

Walaupun data telah menunjukkan bahwa ada perbedaan dalam bentuk penurunan emesis gravidarum, namun hasil ini masih harus diuji signifikansinya. Untuk itu perlu diuji normalitas data menggunakan Uji Shapiro-Wilk. Dan dilanjutnya dengan uji beda nyata.

Tabel 1. Distribusi emesis gravidarum pada ibu hamil trimester satu sebelum dan sesudah minum madu jahe

\begin{tabular}{ccllll}
\hline \multirow{2}{*}{ No } & \multirow{2}{*}{$\begin{array}{c}\text { Emesis ravidarum } \\
\text { trimester tiga }\end{array}$} & pada ibu & \multicolumn{2}{l}{ Sebelum } & \multicolumn{2}{l}{ Sesudah } \\
\cline { 3 - 6 } & $\mathrm{F}$ & $\%$ & $\mathrm{~F}$ & $\%$ \\
\hline 1. & Ringan & 0 & 0 & 7 & 43,8 \\
2. & Sedang & 8 & 50 & 6 & 37,5 \\
3. & Berat & 8 & 50 & 3 & 18,8 \\
\hline Jumlah & & 16 & 100 & 16 & 100 \\
\hline
\end{tabular}

Data yang diperoleh dari monitoring emesis gravidarum ibu hamil trimester satu diuji normalitasnya dengan Uji Shapiro-Wilk. Hasilnya baik sebelum maupun sesudah minum madu jahe datanya tidak normal. Adanya data yang tidak normal, maka metode yang digunakan yaitu metode statistik non-parametrik dengan menggunakan uji Wilcoxon Signed Rank Test seperti yang disajikan pada Tabel 2.

Tabel 2. Perubahan emesis gravidarum pada ibu hamil trimester satu sebelum dan sesudah minum madu jahe

\begin{tabular}{llllll}
\hline Variabel & Keterangan & $\mathrm{N}$ & Mean & St. Deviasi & P-Value \\
\hline \multirow{2}{*}{ Emesis gravidarum } & Sebelum & \multirow{2}{*}{16} & 2,50 & 0,516 & \multirow{2}{*}{0,001} \\
& Sesudah & \multirow{2}{*}{1,75} & 0,775 & \\
\hline
\end{tabular}

Perhitungan perbedaan nilai mean emesis gravidarum pada ibu hamil trimester satu sebelum dan sesudah minum madu jahe sebesar 0,75. Hasil uji Wilcoxon Signed Rank Test untuk emesis gravidarum memiliki signifikansi sebesar $0,001<0,05$, berarti dapat 


\section{Journal of Community Engagement in Health}

http://jceh.org

ISSN: 2620-3758 (print); 2620-3766 (online)

https://doi.org/10.30994/jceh.v3i2.56

Vol.3 No.2. Sep 2020. Page.163-170

disimpulkan terdapat perubahan secara signifikan pada kondisi ibu hamil trismester satu yang mengalami emesis gravidarum sebelum dan sesudah minum madu jahe.

Dari hasil di atas, ibu-ibu hamil trimester satu di wilayah kerja Puskesmas Legok dapat merasakan perbedaan kondisi kehamilannya. Dengan minum madu jahe, rasa mual muntah ditekan oleh jahe, sekaligus dengan adanya madu, membuat badan menjadi segar bersemangat, karena madu mengandung gula sebagai sumber energi yang mudah dikonversi menjadi energi.

\section{KESIMPULAN DAN SARAN}

\section{Kesimpulan}

1. Penyuluhan dan pemberian madu jahe pada ibu hamil trimester satu di Balai Desa Legok, Kabupaten Tangerang bermanfaat bagi ibu hamil trimester satu.

2. Terdapat perbedaan signifikan $[\mathrm{p}(0,004)<\alpha(0,05)]$ emesis gravidarum pada ibu hamil trimester satu, sebelum dan sesudah minum madu jahe secara teratur, selama tujuh hari, di Wilayah Kerja Puskesmas Legok, Kabupaten Tangerang.

3. Minuman madu jahe merupakan salah satu komposisi yang baik untuk menekan emesis gravidarum, sekaligus membuat badan ibu menjadi segar.

\section{Saran}

Untuk ibu hamil diharapkan dapat memanfaatkan minuman jahe madu untuk mengurangi emesis gravidarum sehingga rasa mual muntah dapat ditekan oleh jahe, sekaligus dengan adanya madu, membuat badan menjadi segar bersemangat, karena madu mengandung gula sebagai sumber energi yang mudah dikonversi menjadi energi.

\section{UCAPAN TERIMAKASIH}

Ucapan terimakasih penulis sampaikan pada Wakil Rektor Bidang Penelitian, Pengabdian Masyarakat dan Kerjasama (PPMK) Universitas Nasional dan Kepala Puskesmas Legok, Kabupaten Tangerang dan semua pihak terkait yang telah membantu proses kegiatan pengabdian masyarakat ini

\section{DAFTAR PUSTAKA}

\section{Aly, A.S., Al-Ghamdi, A., Abd El Megeed, M.I., Al Sayegh, A.H. (2013). Effect Of Ginger}

Capsules Intake On Treating Morning Sickness In Early Pregnancy. The Asian Academy of Management Journal. 11(1): 270-286.

Bogdanov, S., Jurendic, T., Sieber, R., Gallmann, P. (2008). Honey for Nutrition and Health: a Review. American Journal of the College of Nutrition. 27: 677-689.

Dipiro, C.V., Talbert, R.L., Yee, G.C., Mattke, G.R., dkk. (2008). Nausea and Vomiting dalam Pharmacotherapy APathophysiologyc Approach, 7th Edition. Mc Graw Hiill Medical.

Herlinadiyaningsih, Hadisaputro, S., Hardjanti, TS., Suwondo, A. (2015). Minuman Jahe Mengurangi Mual Muntah Pada Ibu Hamil. LINK 11(2): 976-981.

Herrell, H.E. (2014). Nausea and Vomiting of Pregnancy. American Family Physician. 89(12): 965-970

Hutagalung, J.S. 2016. Rumah Lebah from Traditional to Modern Medicine. Airlangga University Press. Surabaya.

Lee, N. M., \& Saha, S. (2011). Nausea and vomiting of pregnancy. Gastroenterology clinics

of North America. 40(2), 309-vii. https://doi.org/10.1016/j.gtc.2011.03.009 
Putri, Y.R., Haslina, E., 2020. Asuhan Keperawatan Maternitas pada Kasus Komplikasi Kehamilan, Persalinan dan Nifas. Pena Persada. Purwokerto.

Regina, S.W., Heidy., Selvi, R., dan Marissa, I. (2011). Kegunaan jahe untuk mengatasigejala mual dan muntah dalam kehamilan . Jornal of Medicine Vol. 10 No 3.

Runiari, N. (2010). Asuhan keperawatan pada klien dengan hiperemesis gravidarum: penerapan konsep dan teori keperawatan. Jakarta: Salemba Medika.

Saswita, R. R., Marisah. 2011. Asuhan Kebidanan Pada Masa Persalinan.Jakarta: Salemba Medika.

Wylde, S., Nwose, E., Bwititi, P. (2016). Morning sickness in pregnancy: mini review of possible causes with proposal for monitoring by diagnostic methods. International Journal of Reproduction, Contraception, Obstetrics and Gynecology. 5(2):261-267. DOI: $\underline{\text { http://dx.doi.org/10.18203/2320-1770.ijrcog20160356 }}$ 